\title{
Seroprevalence of Toxoplasma gondii and associated risk factors in domestic pigs raised from Cuba
}

\author{
Julio César Castillo-Cuenca ${ }^{1,2}$ - Álvaro Martínez-Moreno ${ }^{3}$. José Manuel Diaz-Cao² Angel Entrena-García $^{4}$. \\ Jorge Fraga $^{5} \cdot$ Pedro Casanova Arias $^{5}$. Sonia Almería ${ }^{6}$. Ignacio García-Bocanegra ${ }^{2}$ (1)
}

Received: 23 March 2021 / Accepted: 9 July 2021

(c) The Author(s) 2021

\begin{abstract}
A cross-sectional study was carried out to determine the seroprevalence of Toxoplasma gondii and associated risk factors in pigs in the largest pork-producing region in Cuba. Serum samples from 420 pigs, including 210 sows and 210 post-weaning pigs, were tested for antibodies against $T$. gondii using a commercial indirect enzyme-linked immunosorbent assay. AntiT. gondii antibodies were detected in 56 animals (13.3\%, 95\% CI: 10.1-16.6). A generalized estimating equations model revealed that the risk factors associated with higher seropositivity in pigs were altitude (higher in farm's location $<250 \mathrm{~m}$ above sea level (masl) versus $\geq 250$ masl) and age (higher in sows compared to post-weaning pigs). The results indicated that this protozoan parasite is widely distributed on pig farms in the study area, which is a public health concern since the consumption of raw or undercooked pork meat products containing tissue cysts is considered one of the main routes of $T$. gondii transmission worldwide. Control measures should be implemented to reduce the risk of exposure to T. gondii in pigs in Cuba.
\end{abstract}

Keywords Toxoplasma gondii $\cdot$ Seroprevalence $\cdot$ Domestic pigs $\cdot$ Public health $\cdot$ Cuba

Section Editor: Xing-Quan ZHU

Ignacio García-Bocanegra

nacho.garcia@uco.es

1 Departamento, de Medicina Veterinaria Y Zootecnia, Facultad de Ciencias Agropecuarias, Universidad Central "Marta Abreu" de Las Villas, Villa Clara, 54830 Santa Clara, Cuba

2 Animal Health and Zoonosis Research Group (GISAZ), Department of Animal Health, University of Cordoba, 14014 Córdoba, Spain

3 Department of Animal Health (Parasitology and Parasitic Diseases), University of Cordoba, 14014 Córdoba, Spain

4 Departamento de Parasitología, Centro Nacional Para La Producción de Animales de Laboratorio (CENPALAB), 10300 La Habana, Cuba

5 Departamento de Parasitología, Instituto de Medicina Tropical Pedro Kourí, 11400 La Habana, Cuba

6 Department of Health and Human Services, Food and Drug Administration, Center for Food Safety and Nutrition (CFSAN), Office of Applied Research and Safety Assessment (OARSA), Division of Virulence Assessment, Laurel, MD, USA

\section{Introduction}

Toxoplasmosis is a worldwide zoonotic disease caused by the obligate intracellular protozoan parasite, Toxoplasma gondii, which infects virtually all warm-blooded species including human beings (Dubey et al. 2020). Approximately one-third of the human population is considered to be infected by this protozoan parasite (Behnke et al. 2020). Although $T$. gondii infection is usually asymptomatic, it can cause abortion, as well as blindness, neuromuscular disease, and even death in immunocompromised people (Dubey 2010). Moreover, an association between toxoplasmosis and neuropsychiatric disorders, including schizophrenia, has been suggested (Flegr and Horáček 2017).

Toxoplasma gondii is an important food-borne pathogen (EFSA 2018). The consumption of raw or undercooked meat products containing tissue cysts is considered one of the main routes of $T$. gondii transmission worldwide (Dubey 2010; Almeria and Dubey 2021). In this respect, pork is one of the major sources of human toxoplasmosis in some countries (Dubey et al. 2020; Almeria and Dubey 2021). Public concerns associated with $T$. gondii clearly indicate the need for epidemiological investigation in animals that can be used as a source of food. Previous immunological studies 
on the presence of $T$. gondii antibodies in domestic pigs carried out in Latin America showed wide variations in the seroprevalence among countries and between regions within the same country (Cañón-Franco et al. 2014; Feitosa et al. 2014; Foroutan et al. 2019; Dubey et al. 2020). In Cuba, anti-T. gondii antibodies have been found in human patients with acquired immunodeficiency syndrome (Alfonso et al. 2009) and retinochoroiditis (Regalado Andújar et al. 2013), in pregnant women (González-Morales et al. 1995), neonates (Goya Batista et al. 2014), and blood donors (SánchezArtigas et al. 2009). Seropositivity has also been reported in domestic animals, including cats (Grandía et al. 2012) and dogs (Navarrete et al. 2017) in this country. Nevertheless, information regarding $T$. gondii in domestic pigs in Cuba is very scarce. The only previous survey in this species was carried out in Ciego de Ávila province (Central Cuba) between 1980 and 2002 (Suárez-Hernández et al. 2005). Hence, the aim of this study was to assess the current seroprevalence and risk factors associated with $T$. gondii in pigs in the largest pork-producing region in Cuba.

\section{Material and methods}

\section{Study design}

A cross-sectional study was carried out to determine seroprevalence against $T$. gondii in domestic pigs in Villa Clara (Central Cuba) (Fig. 1). This region accounts for the highest number of domestic pigs and is the largest pork producer in Cuba, with annual production at around 49,332 tons (ONEI 2017). Pork production in Cuba is characterized by an agreement management system. This means that all breeding farms, including sows, reproductive males, and piglets (from post-farrowing to post-weaning), are managed by the State government in intensive production systems. Fattening

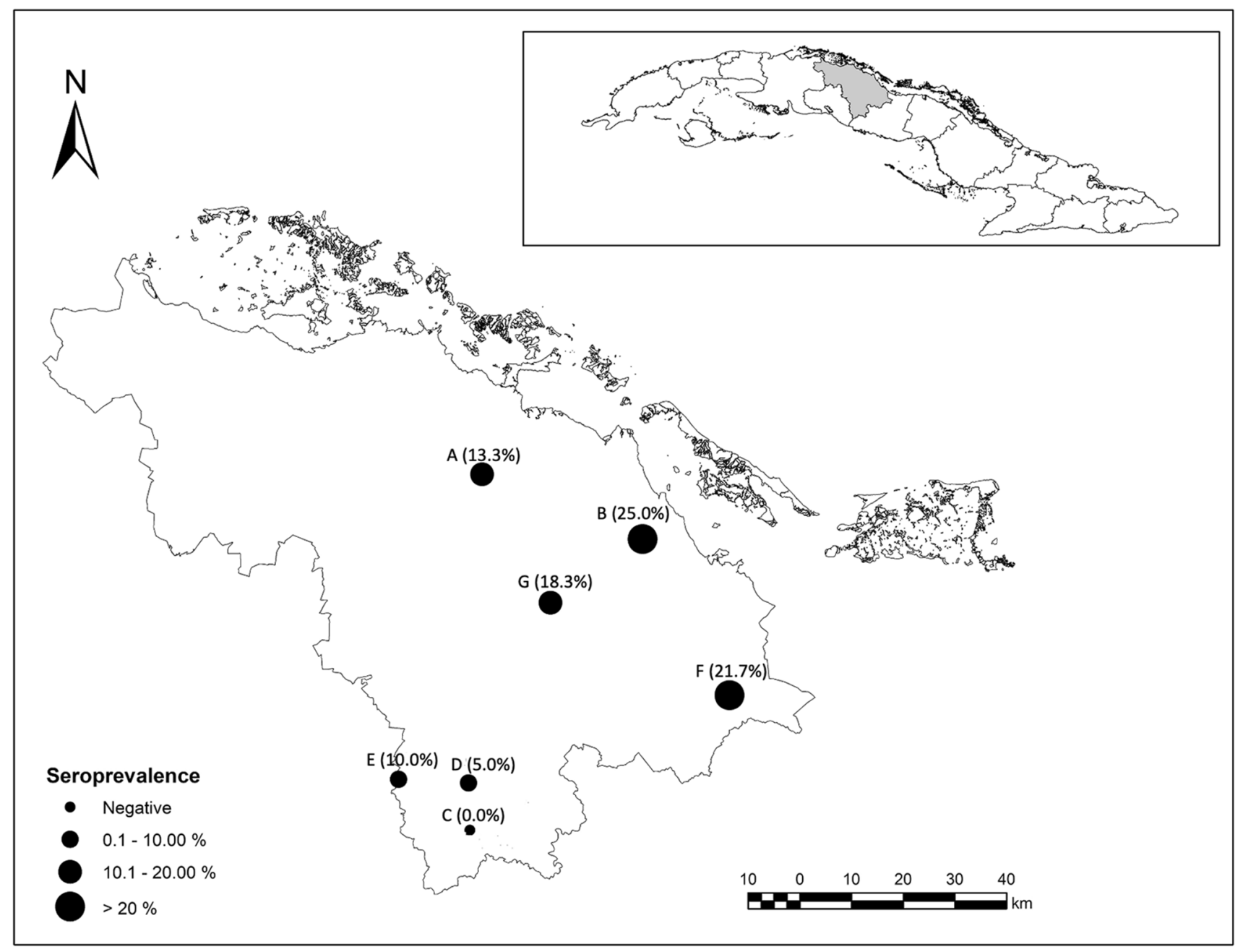

Fig. 1 Map of Villa Clara province (Cuba) showing the distribution and within-farm seroprevalence of Toxoplasma gondii on the sampled pig farms 
is then carried out by private swine farmers until the pigs are ready for slaughter.

The total population of all breeding farms in the study area was used to calculate sampling size. The size of the sampled farms ranged from 500 to 1,600 sows (mean: 1,050 sows). The breeds of the sows and post-weaning pigs were Yorkshire/Landrace and Yorkshire/Landrace X CC21 (Cuban paternal breed), respectively. Sample size was calculated assuming a prevalence of $50 \%$ (which provides the highest sample size in studies with unknown prevalence) with a 95\% confidence level $(95 \% \mathrm{CI})$ and desired precision of $\pm 5 \%$, resulting in 384 domestic pigs to be sampled (Thrusfield et al. 2018). Sixty animals, including 30 sows and 30 post-weaning pigs, were randomly selected from each pig farm in order to detect infection with $95 \%$ probability and assuming a minimum within-farm prevalence of $6 \%$. A total of 420 pigs were finally sampled in seven $(A-G)$ farms managed under governmental intensive production management. All sampled farms presented very similar biosecurity measures including self-replacement gilts (replacement of breeding sows using gilts from the same herd), all-in-all out management, absence of cats, absence of other animal species, perimetral fence around the farm, rodent and insect control, disinfection and disinfestations protocols, sanitary ford, and water chlorination, among others. Farms A, B, F, and $\mathrm{G}$ were located $<250 \mathrm{~m}$ above sea level (masl), while farms $\mathrm{C}, \mathrm{D}$, and $\mathrm{E}$ were located at altitudes $\geq 250$ masl.

\section{Sample collection and serological analysis}

The collection of samples analyzed in the present study was part of the official Animal Health Campaigns under Cuban legislation. No animals were specifically sampled for this study; therefore, no ethical approval was necessary. Blood samples (about $10 \mathrm{ml}$ ) were collected using the orbital sinus puncture method. Samples were then centrifuged at 4,800 rpm for $10 \mathrm{~min}$. Serum samples were separated and stored at $-20{ }^{\circ} \mathrm{C}$ until analysis. To obtain the presence of the antibodies against $T$. gondii, serum samples were analyzed using a commercial indirect ELISA (PrioCHECK ${ }^{\circledR}$ Toxoplasma Ab porcine, Thermo Fisher Scientific Prionics Lelystad BV) in accordance with the manufacturer's recommendations (Castillo-Cuenca et al. 2020). The sensitivity and specificity of this ELISA according to the manufacturer are $98 \%$ and $99.6 \%$, respectively.

\section{Statistical analysis}

Individual seroprevalence against $T$. gondii was calculated as the ratio of seropositive animals to the total number of animals examined, using two-sided exact binomial confidence intervals (95\% CI). Analysis of means (ANOM) applied to proportions was used to identify farms with a significantly different within-farm seroprevalence relative to the overall mean combining all the sampled farms ("grand mean"), enabling detection of groups that deviate significantly from the overall mean (Rao 2005). The analysis was performed using the "ANOM" package (Pallmann and Hothorn 2016) of the statistical software $R(R$ v. 3.5.2). If a statistically significant difference between the farms was found by ANOM, a dummy variable was created ("significantly different farm" vs "other farms") and included in the bivariate analysis.

Epidemiological information including age, sex, farm (from A to G), altitude, and farm size was gathered for each sampled animal. For sows, data on offspring per birth, number of parities, weaning piglets, and stillbirths were also recorded. Bivariate chi-square and Fisher's exact tests were performed to obtain the statistical significance of independent variables regarding individual $T$. gondii status (dependent variable). Variables with $P<0.20$ in the bivariate analysis were selected as potential risk factors. Collinearity between pairs of variables was tested by Cramer's $V$ coefficient. Finally, a generalized estimating equation (GEE) was carried out to study the effect of the variables selected on the basis of bivariate analysis (Thrusfield et al. 2018). The number of seropositive animals was assumed to follow a binomial distribution and the "farm" was included as random effect. A logarithmic link function was considered. A forward introduction of variables was used, starting with the variable with the lowest $P$ value in bivariate analysis. At each step, the confounding effect of the included variable was assessed by computing the change in the odds ratios (ORs). The model was re-run until all remaining variables presented statistically significant values (likelihood-ratio Wald's test, $P<0.05)$ and a potential relationship with the response variable existed. The choice of the best model was based on the quasi-likelihood under independence model criterion (Hanley et al. 2003). Statistical analyses were performed using SPSS v25.0 software (Statistical Package for Social Sciences, Inc., Chicago, IL, USA).

\section{Results}

Antibodies against $T$. gondii were detected in 56 of 420 pigs tested (13.3\%, 95\% CI: 10.1-16.6). Seropositivity was found in six of the seven $(85.7 \%)$ tested farms, and the withinfarm seroprevalence ranged between 5.0 and $25 \%$ : with the highest seroprevalence observed in pigs from farm B and the lowest value in pigs from farm $\mathrm{D}$ had the lowest value. Interestingly, antibodies against $T$. gondii were not found in samples from farm C (Table 1) (Fig. 1). ANOM showed a significant lower seroprevalence on farm "C," which was negative to the presence of anti-T. gondii antibodies, in relation to the overall mean of the other farms tested (Fig. 2). 
Table 1 Distribution of the prevalence of antibodies against Toxoplasma gondii, using ELISA, on pig farms in Villa Clara province (Cuba) by category. Variables with $P$-value $<0.20$ in the bivariate

\begin{tabular}{|c|c|c|c|c|c|c|}
\hline Variable & Categories & $\begin{array}{l}\text { Number/overall (\% } \\
\text { positive) }\end{array}$ & OR & $95 \% \mathrm{CI}$ & Chi-square & $P$-value \\
\hline \multirow[t]{7}{*}{ Farm } & A & $8 / 60(13.3)$ & \multirow[t]{7}{*}{ NA } & & 25.385 & $<0.001$ \\
\hline & B & $15 / 60(25.0)$ & & & & \\
\hline & $\mathrm{C}$ & $0 / 60(0.0)$ & & & & \\
\hline & $\mathrm{D}$ & $3 / 60(5.0)$ & & & & \\
\hline & E & $6 / 60(10.0)$ & & & & \\
\hline & $\mathrm{F}$ & $13 / 60(21.7)$ & & & & \\
\hline & G & $11 / 60(18.3)$ & & & & \\
\hline \multirow[t]{2}{*}{ Altitude ( $\mathrm{m}$ above sea level) } & $<250$ & $47 / 240(19.6)$ & 4.627 & \multirow[t]{2}{*}{$2.20-9.72$} & \multirow[t]{2}{*}{18.830} & $<0.001$ \\
\hline & $\geq 250$ & $9 / 180(5.0)$ & $*$ & & & \\
\hline \multirow[t]{2}{*}{ Farm size } & $>501$ & $23 / 120(19.2)$ & 1.918 & \multirow[t]{2}{*}{$1.07-3.43$} & \multirow[t]{2}{*}{4.497} & 0.022 \\
\hline & $<500$ & $33 / 300(11.0)$ & $*$ & & & \\
\hline \multirow[t]{2}{*}{ Age } & Sows & $46 / 210(21.9)$ & 5.610 & \multirow[t]{2}{*}{$2.75-11.5$} & \multirow[t]{2}{*}{26.703} & $<0.001$ \\
\hline & Post-weaning pigs & $10 / 210(4.8)$ & $*$ & & & \\
\hline \multirow[t]{2}{*}{ Sex } & Male & $4 / 106(3.8)$ & 0.627 & \multirow[t]{2}{*}{$0.17-2.29$} & \multirow[t]{2}{*}{0.505} & 0.350 \\
\hline & Female & $6 / 102(5.9)$ & $*$ & & & \\
\hline \multirow[t]{2}{*}{ Offspring per birth } & $<9$ & $10 / 32(31.3)$ & 0.558 & \multirow[t]{2}{*}{$0.24-1.28$} & \multirow[t]{2}{*}{1.927} & 0.125 \\
\hline & $\geq 10$ & $36 / 178(20.2)$ & $*$ & & & \\
\hline \multirow[t]{2}{*}{ Parity number } & $<3$ & $30 / 116(25.9)$ & 0.588 & \multirow[t]{2}{*}{$0.30-1.16$} & \multirow[t]{2}{*}{1.927} & 0.125 \\
\hline & $\geq 4$ & 16/94 (17.0) & $*$ & & & \\
\hline \multirow[t]{2}{*}{ Weaning piglets } & $<9$ & $10 / 47(21.3)$ & 1.05 & \multirow[t]{2}{*}{$0.48-2.31$} & \multirow[t]{2}{*}{0.014} & 0.541 \\
\hline & $\geq 10$ & $36 / 163(22.1)$ & $*$ & & & \\
\hline \multirow[t]{2}{*}{ Still birth } & Yes & 12/67 (17.9) & 0.70 & \multirow[t]{2}{*}{$0.34-1.46$} & \multirow[t]{2}{*}{0.918} & 0.220 \\
\hline & No & $34 / 143(23.8)$ & $*$ & & & \\
\hline
\end{tabular}

NA not applicable; *reference category

Fig. 2 Results of the analysis of means comparing seroprevalences on the sampled farms analysis were included in the multivariate analysis (generalized estimating equation) to determine potential risk factors

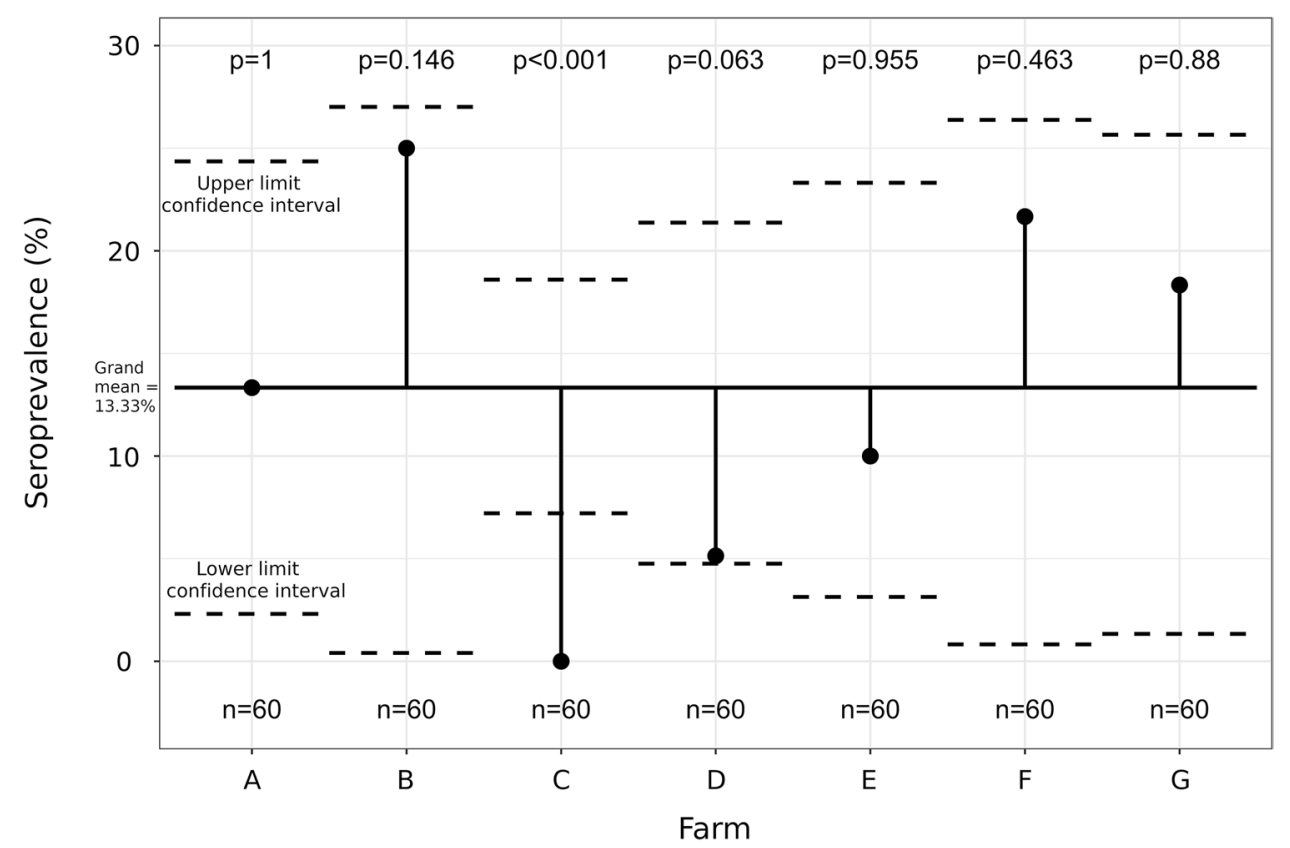


No association between seropositivity to $T$. gondii and sex, offspring per weaning piglets, and still birth was found in the bivariate analysis. Farm, altitude, farm size, age, offspring per birth, and parity number were selected for the multivariate analysis (Table 1). The final GEE model showed that the main factors associated with $T$. gondii seropositivity in pigs in Cuba were altitude and age. The prevalence of $T$. gondii antibodies was significantly higher on farm located <250 masl (19.6\%; 95\% CI: 14.6-24.6) compared to the farms located at altitude $\geq 250$ masl $(5.0 \% ; 95 \%$ CI: $1.8-8.2)(\mathrm{OR}=5.28 ; P=0.001 ; 95 \% \mathrm{CI}: 1.91-14.57)$. Significantly higher seropositivity was also found in sows (21.9\%; 95\% CI: 16.3-27.5) compared to post-weaning pigs $(4.8 \%$; 95\% CI: $1.8-7.6)(\mathrm{OR}=6.05 ; P<0.001 ; 95 \%$ CI: 2.53-14.60).

\section{Discussion}

Consumption of contaminated undercooked or raw meat from farm animals has been known to be a major risk factor for acquisition of $T$. gondii infection in humans, and among food livestock species, pork is considered one of the main sources of $T$. gondii infection (Almeria and Dubey 2021). The first key step to prevent transmission of this zoonotic parasite in the swine production is to determine the presence of the parasite in the farms. In this regard, serological surveillance is the most commonly used method tool for identifying $T$. gondii exposure in pigs.

The individual seroprevalence detected in pigs raised in Cuba in our study (13\%) is of the same magnitude as found previously in Cuba (14\%) and in other Latin American countries such as Brazil (13\%), Colombia (15\%), and Mexico (ranging between 13 and 17\%) (Suárez-Hernández et al. 2005; Foroutan et al. 2019; Dubey et al. 2020). Slightly higher mean seroprevalence values were observed in Brazil (ranging between 20 and 26\%), while higher seropositivity was found in Argentina (48\%), Brazil (ranging between 33 and 52\%), Costa Rica (44\%), Hawaii (49\%), Mexico (ranging between 45 and 97\%), Panamá (32\%), and Peru (30\%) (Cañón-Franco et al. 2014; Foroutan et al. 2019; Dubey et al. 2020). In contrast, lower seroprevalence rates were detected in other studies in Brazil (ranging between 0 and 8\%), Chile (9\%), and Mexico (ranging between 1 and 9\%) (Foroutan et al. 2019; Dubey et al. 2020). Even though statistically accurate comparisons cannot be made given the differences in number of animals tested, the population sampled, and/ or the different serological methods used, we would like to state that the seroprevalence in pigs in the study area should be considered moderate.

At least one seropositive pig was detected in six of the seven $(85.7 \%)$ farms tested, with positive within-farm seroprevalence values ranging between 5.0 and $25.0 \%$. Although farm " $\mathrm{C}$ " was negative to the presence of anti- $T$. gondii antibodies, the number of samples collected in each farm was calculated assuming a minimum within-farm prevalence of $6 \%$ and therefore, the possibility of that particular farm having a seroprevalence lower than 5\% could not be discounted. The results indicated that $T$. gondii infection is widespread on pig breeding farms in Cuba. Since the sampled farms were all managed under a very similar production system, the environmental characteristics may explain differences in the seroprevalences in pigs within the study region. In this regard, farms located $<250$ masl showed significantly higher seropositivity compared to the raised at higher altitude. Our results are in agreement with those reported by Villari et al. (2009) who consider the higher altitude ( $>200$ masl) of the farms as a protective factor of $T$. gondii exposure; this observation is likely associated with a reduced environmental viability of oocysts with decreasing ambient temperature and, perhaps, also humidity. Higher seroprevalence levels were also found in wild boars (Sus scrofa) sampled in hunting states located $<600$ masl compared to those sampled at higher altitude (Calero-Bernal et al. 2016). In contrast, other studies observed higher seropositivity to $T$. gondii in pigs raised in mountainous regions than those raised in lowlands (Alvarado-Esquivel et al. 2012; Papatsiros et al. 2016). The reason for these differences is unclear; however, environmental, and climatic conditions may impact survival of oocysts in soil, food, and water contaminated with feline feces (Gauss et al. 2006), which are the likely sources of infection for pigs. Further studies are needed to address this issue.

Significantly higher seropositivity was found in sows compared to post-weaning pigs. Age is an important factor affecting $T$. gondii seroprevalence in pigs because most animals acquire $T$. gondii infection postnatally (Dubey 2009). The higher prevalence of $T$. gondii antibodies in sows compared to post-weaning pigs is consistent with those previously reported (García-Bocanegra et al. 2010a; Hill et al. 2014; Djokic et al. 2016; Castillo-Cuenca et al. 2020) and probably reflects the cumulative likelihood of exposure to $T$. gondii and lifelong persistence of IgG antibodies. Maternalderived antibodies decline after the first week of age, but the decay is dependent on the antibody level of the dam at birth. However, because maternally transferred antibodies can persist until 4 months of age (Dubey 2009; García-Bocanegra et al. 2010b), the presence of maternally transferred antibodies detected in some seropositive post-weaning pigs cannot be ruled out.

Toxoplasmosis outbreaks have been reported in humans by ingestion of infected porcine meat containing tissue cysts (Choi et al. 1997; Vitale et al. 2014; Almeria and Dubey 2021). Even though we are not aware of any report of human toxoplasmosis directly linked to eating infected pork in Cuba, ocular toxoplasmosis (Mesa Hernández et al. 
2011; Galbán Lueje et al. 2013; Bustillo et al. 2015; Ginorio Gavito et al. 2017), toxoplasmic encephalitis in patients with acquired immunodeficiency syndrome (Alfonso et al. 2009), acute toxoplasmosis in pregnant women (Lombana et al. 2012), and congenital toxoplasmosis (Amador Morán et al. 2016) have been reported in this country. Moreover, seropositivity values found in pregnant women (38\%) (GonzálezMorales et al. 1995), neonates (23\%) (Goya Batista et al. 2014), and blood donors (13\%) (Sánchez-Artigas et al. 2009) indicate that $T$. gondii is widely distributed in the human population in Cuba. Since viable $T$. gondii can be found in seropositive pigs, our results suggest that the consumption of non-properly cooked pork products may contribute to human toxoplasmosis in Cuba, and studies on the zoonotic impact of this disease are urgently needed in this country.

In summary, this is the first report on $T$. gondii in pigs in Villa Clara province, the largest pork-producing region in Cuba. Although the number of sampled farms was limited, the results obtained provide a first approximation to $T$. gondii exposure in domestic pigs in a country where there was no recent information in this animal species. The observed seropositivity indicates that this zoonotic parasite is widespread in pig breeding farms in the largest pork-producing region in Cuba. This finding indicates a public health concern because seropositive pigs can harbor tissue cysts in their meat, therefore representing a tentative zoonotic risk for consumers of raw or undercooked porcine meat or its products. In addition, evisceration and management of carcasses of infected pigs could also constitute a risk of infection for humans. Our results may contribute to the development of improved control strategies against $T$. gondii in this country. Further immunological and molecular studies on genotypes circulating in pig farms must be conducted to increase the knowledge of the epidemiology of $T$. gondii in Cuba.

\begin{abstract}
Acknowledgements We would like to thank the Asociación Universitaria Iberoamericana de Postgrado (AUIP, in Spanish) for funding the doctoral training of the first author of this research. We would also like to thank the members of the Epizootiology Department of the Swine Company in Villa Clara, and the team of the Quality Area of the National Center for Animal Production Laboratories (CENPALAB in Spanish) for their help in the sampling and analysis of the collected samples, respectively.
\end{abstract}

Funding Open Access funding provided thanks to the CRUE-CSIC agreement with Springer Nature. Universidad de Córdoba/CBUA.

\section{Declarations}

Conflict of interest The authors declare no competing interests.

Open Access This article is licensed under a Creative Commons Attribution 4.0 International License, which permits use, sharing, adaptation, distribution and reproduction in any medium or format, as long as you give appropriate credit to the original author(s) and the source, provide a link to the Creative Commons licence, and indicate if changes were made. The images or other third party material in this article are included in the article's Creative Commons licence, unless indicated otherwise in a credit line to the material. If material is not included in the article's Creative Commons licence and your intended use is not permitted by statutory regulation or exceeds the permitted use, you will need to obtain permission directly from the copyright holder. To view a copy of this licence, visit http://creativecommons.org/licenses/by/4.0/.

\section{References}

Alfonso Y, Fraga J, Fonseca C et al (2009) Molecular diagnosis of Toxoplasma gondii infection in cerebrospinal fluid from AIDS patients. Cerebrospinal Fluid Res 6:2. https://doi.org/10.1186/ 1743-8454-6-2

Almeria S, Dubey JP (2021) Foodborne transmission of Toxoplasma gondii infection in the last decade. An overview. Res Vet Sci 135:371-385. https://doi.org/10.1016/j.rvsc.2020.10.019

Alvarado-Esquivel C, Estrada-Malacón MA, Reyes-Hernández SO et al (2012) High prevalence of Toxoplasma gondii antibodies in domestic pigs in Oaxaca State, Mexico. J Parasitol 98:1248 1250. https://doi.org/10.1645/GE-3184.1

Amador Morán R, Coutos Ramos MJ, Peña Cedeño A et al (2016) Presentación de un caso con toxoplasmosis congénita. Rev Cuba Obstet y Ginecol 42. http://revginecobstetricia.sld.cu/index.php/ gin/article/view/47/31. Accessed Feb 2021

Behnke MS, Saeij JPJ, Boyle JP (2020) Development and application of classical genetics in Toxoplasma gondii. In: Toxoplasma gondii, Thirth. Wiess, L.M. and Kim, K. Academic Press, Elsevier, p 859-896. https://doi.org/10.1016/B978-0-12-815041-2. 00019-0

Bustillo JL, Diaz JD, Pacheco IC, Gritz DC (2015) Cuban ocular toxoplasmosis epidemiology study (COTES): incidence and prevalence of ocular toxoplasmosis in Central Cuba. Br J Ophthalmol 99:382-386. https://doi.org/10.1136/bjophthalmol-2014-305843

Calero-Bernal R, Pérez-Martín JE, Reina D et al (2016) Detection of zoonotic protozoa Toxoplasma gondii and Sarcocystis suihominis in wild boars from Spain. Zoonoses Public Health 63:346-350. https://doi.org/10.1111/zph.12243

Cañón-Franco WA, López-Orozco N, Gómez-Marín JE, Dubey JP (2014) An overview of seventy years of research (1944-2014) on toxoplasmosis in Colombia. South America Parasit Vectors 7:427. https://doi.org/10.1186/1756-3305-7-427

Castillo-Cuenca JC, Díaz-Cao JM, Martínez-Moreno Á et al (2020) Seroepidemiology of Toxoplasma gondii in extensively raised Iberian pigs in Spain. Prev Vet Med 175:104-854. https://doi.org/10. 1016/j.parint.2010.06.001

Choi W-Y, Nam H-W, Kwak N-H et al (1997) Foodborne outbreaks of human toxoplasmosis. J Infect Dis 175:1280-1282. https://doi. org/10.1086/593702

Djokic V, Fablet C, Blaga R et al (2016) Factors associated with Toxoplasma gondii infection in confined farrow-to-finish pig herds in western France: an exploratory study in 60 herds. Parasit Vectors 9:466. https://doi.org/10.1186/s13071-016-1753-5

Dubey JP (2010) Toxoplasmosis of animals and humans. Second. CRC Press Taylor \& Francis Group, New York

Dubey JP (2009) Toxoplasmosis in pigs - the last 20 years. Vet Parasitol 164:89-103. https://doi.org/10.1016/j.vetpar.2009.05.018

Dubey JP, Cerqueira-Cézar CK, Murata FHA et al (2020) All about Toxoplasma gondii infections in pigs: 2009-2020. Vet Parasitol 288:109-185. https://doi.org/10.1016/j.vetpar.2020.109185

EFSA (2018) Public health risks associated with food-borne parasites. EFSA J 16:e05495. https://doi.org/10.2903/j.efsa.2018.5495 
Feitosa TF, Vilela VLR, Bezerra de Melo LR et al (2014) Toxoplasma gondii and Neospora caninum in slaughtered pigs from Northeast, Brazil. Vet Parasitol 202:305-309. https://doi.org/10.1016/j.vetpar.2014.03.015

Flegr J, Horáček J (2017) Toxoplasma-infected subjects report an Obsessive-compulsive disorder diagnosis more often and score higher in Obsessive-Compulsive Inventory. Eur Psychiatry 40:8287. https://doi.org/10.1016/j.eurpsy.2016.09.001

Foroutan M, Fakhri Y, Riahi SM et al (2019) The global seroprevalence of Toxoplasma gondii in pigs: a systematic review and metaanalysis. Vet Parasitol 269:42-52. https://doi.org/10.1016/j.vetpar. 2019.04.012

Galbán Lueje T de las M, Lima León CE, Fariñas Falcón Z et al (2013) Caracterización de la toxoplasmosis ocular en pacientes de consulta externa. Acta Med 7:12-22. https://www.medigraphic.com/ pdfs/medicadelcentro/mec-2013/mec134c.pdf. Accessed Oct 2020

García-Bocanegra I, Simon-Grifé M, Dubey JP et al (2010a) Seroprevalence and risk factors associated with Toxoplasma gondii in domestic pigs from Spain. Parasitol Int 59:421-426. https://doi. org/10.1016/j.parint.2010.06.001

García-Bocanegra I, Simon-Grifé M, Sibila M et al (2010b) Duration of maternally derived antibodies in Toxoplasma gondii naturally infected piglets. Vet Parasitol 170:134-136. https://doi.org/10. 1016/j.vetpar.2010.01.042

Gauss CBL, Dubey JP, Vidal D et al (2006) Prevalence of Toxoplasma gondii antibodies in red deer (Cervus elaphus) and other wild ruminants from Spain. Vet Parasitol 136:193-200. https://doi.org/ 10.1016/j.vetpar.2005.11.013

Ginorio Gavito DE, Vilches Lescaille D, Gracial X et al (2017) Toxoplasmosis ocular: Algunos hallazagos clínicos y seroepidemiológicos. Rev AACC 7:4-13. http://revistaccuba.sld.cu/index. $\mathrm{php} / \mathrm{revacc} / \mathrm{article} / \mathrm{view} / 352 / 352$. Accessed Nov 2020

González-Morales T, Bacallo-Gallestey J, García-Santana CA, MolinaGarcía JR (1995) Prevalencia de anticuerpos anti-Toxoplasma gondii en una población de mujeres embarazadas en Cuba. Gac Méd Méx 131:400. https://www.anmm.org.mx/bgmm/1864_2007/ 1995-131-5-6-499-503.pdf. Accessed Mar 2021

Goya Batista Y, Sánchez Artigas R, Cobos Valdes D et al (2014) Determinación de anticuerpos IgG contra Toxoplasma gondii en neonatos de la Sala de Neonatología del Hospital General Universitario "Vladimir Ilich Lenin", Holguín. Rev Cuba Investig Biomed 33:12-18. http://scielo.sld.cu/pdf/ibi/v33n1/ibi02114.pdf. Accessed Oct 2020

Grandía R, Entrena Á, Cruz J et al (2012) Seroprevalencia de Toxoplasma gondii y factores de riesgo asociados en Felis catus en La Habana. Rev Salud Anim 34:201. http://scielo.sld.cu/scielo.php? script $=$ sci_arttext\&pid=S0253-570X2012000300013. Accessed Nov 2020

Hanley JA, Negassa A, Edwardes MD, Forrester JE (2003) Statistical analysis of correlated data using generalized estimating equations : an orientation. Am J Epidemiol 157:364-375. https://doi. org/10.1093/aje/kwf215

Hill DE, Dubey JP, Baroch JA et al (2014) Surveillance of feral swine for Trichinella spp. and Toxoplasma gondii in the USA and hostrelated factors associated with infection. Vet Parasitol 205:653665. https://doi.org/10.1016/j.vetpar.2014.07.026
Lombana RS, Cabrera MPC, Gavito DG et al (2012) Toxoplasmosis y embarazo. Rev Cuba Obstet Ginecol 38:99-106. http://scielo.sld. cu/pdf/gin/v38n1/gin12112.pdf. Accessed Nov 2020

Mesa Hernández E, González Peña O, Padilla González C et al (2011) Comportamiento de la toxoplasmosis ocular activa en el Instituto Cubano de Oftalmología “Ramón Pando Ferrer". Rev Cuba Oftalmol 24:124-135. http://scielo.sld.cu/pdf/oft/v24n1/oft12111.pdf. Accessed Oct 2020

Navarrete MG, Cordeiro MD, Batista Y et al (2017) Serological detection of Toxoplasma gondii in domestic dogs in the western region of Cuba. Vet Parasitol Reg Stud Reports 9:9-12. https://doi.org/ 10.1016/j.vprsr.2017.03.005

ONEI (2017) Anuario Estadístico de la Provincia de Villa Clara. La Habana. http://www.onei.gob.cu/mapa/provincia/villa-clara. Accessed March 2021

Pallmann P, Hothorn LA (2016) Analysis of means: a generalized approach using R. J Appl Stat 43:1541-1560. https://doi.org/10. 1080/02664763.2015.1117584

Papatsiros VG, Athanasiou LV, Stougiou D et al (2016) Cross-sectional serosurvey and risk factors associated with the presence of Toxoplasma gondii antibodies in pigs in Greece. Vector Borne Zoonotic Dis 16:48-53. https://doi.org/10.1089/vbz.2015.1845

Rao CV (2005) Analysis of means-a review. J Qual Technol 37:308315. https://doi.org/10.1080/00224065.2005.11980334

Regalado Andújar B, Rodríguez Peña MS, Fraga Nodarse J, et al (2013) Aplicación de herramientas serológicas y moleculares para el diagnóstico de coriorretinitis por Toxoplasma gondii. Rev Cuba Med Trop 65:13-25. http://scielo.sld.cu/scielo.php?script=sci_ arttext\&pid=S0375-07602013000100003. Accessed Feb 2021

Sánchez-Artigas R, Góngora-Amores W, Torres-Ponce Z, CastañedaComerón B (2009) Seroprevalencia de anticuerpos IgG anti-Toxoplasma gondii en donantes especiales de sangre en el municipio de Holguín. Ciencias Holguín 15:1-8. http://www.ciencias.holgu in.cu/index.php/cienciasholguin/article/view/529. Accessed Feb 2021

Suárez-Hernández M, González-Fernández A, Gardón-Quirola BY, Martínez-Sánchez R (2005) Infección y enfermedad por Toxoplasma gondii en animales y humanos en 23 años de observación en la provincia de Ciego de Ávila, Cuba. Rev Biomed 16:2127. https://www.medigraphic.com/cgi-bin/new/resumen.cgi? IDARTICULO=7396. Accessed Mar 2021

Thrusfield M, Christley R, Brown H et al (2018) Veterinary epidemiology. Fourth. John Wiley \& Sons, Oxford

Villari S, Vesco G, Petersen E et al (2009) Risk factors for toxoplasmosis in pigs bred in Sicily, Southern Italy. Vet Parasitol 161:1-8. https://doi.org/10.1016/j.vetpar.2009.01.019

Vitale M, Tumino G, Partanna S et al (2014) Impact of traditional practices on food safety: a case of acute toxoplasmosis related to the consumption of contaminated raw pork sausage in Italy. J Food Prot 77:643-646. https://doi.org/10.4315/0362-028X.JFP-13-285

Publisher's note Springer Nature remains neutral with regard to jurisdictional claims in published maps and institutional affiliations. 